\title{
DIE ORGANIESE EENHEID VAN OBJEKTIEWE BYBELONDERSOEK.*
}

"Wie die Kerk van ,die Woord' in watter hoedanigheid ook wil dien, moet voor alles in ,die Woord', dit is die Heilige Skrif, grondig tuis wees. Vir die Middeleeuse geleerde het die homo biblicus as nog maar 'n beginneling in die Sancta Theologia, gegeld, as een wat ver onder hom staan wat in die geheimenisse van die teologiese en filosofiese leersisteme ingelei was. Vir die Protestantse beskouing lê sake juis omgékeerd. Die Protestante is gewoon om te glo dat die filosofiese en teologiese spekulasies kom en gaan, maar dat , die Woord van onse God stand hou in ewigheid (Jes. 40:8). Daarom is vir hulle die Skrifstudie grondslag en doel van alle teologiese arbeid."

Met hierdie behartenswaardige, egt-reformatoriese woorde van die Outestamenticus Johannes Meinhold ') wil ek graag die akademiese kursus 1945 van die Hervormde Kerk se afdeling van die Teologiese Fakulteit open. Ek ag my gelukkig om te weet dat al vier die professore van ons Afdeling hierdie beginselverklaring van harte onderskryf en dat daar in hierdie prinsipiële saak nie die minste verskil van oortuiging onder ons vier bestaan nie. En my hartewens is dat ons studente eweseer erns sal maak met hierdie gulde woorde, wat hulle gerus, inpleks van allerlei ander leuse waarvan ons tyd so verwarrend vol is, as die leidende motief van hulle studietyd aan ons Universiteit kan kies: „Wie die Kerk van ,die Woord' wil dien, moet voor alles in ,die Woord' grondig tuis wees.... Skrifstudie is grondslag en doel van alle teologiese arbeid."

Die waardigheid van die Skrif bring egter mee dat dit 'n onbevange ondersoek moet wees. Ons kan natuurlik ander mense nie verhinder nie -- en dit sou aanmatigend klink om hulle die reg te ontsê - om op húlle wyse die Skrif te benader. Daar is ondersoekers wat die Skrif wil benader vanuit die standpunt dat dit 'n bloot-menslike geskriftebundel uit die verre oudheid is. Daar is ander ondersoekers wat by hulle Skrifondersoek wil uitgaan van teologies-dogmatiese beskouings, selfs vanuit as wetsreglemente toegepaste kerklike belydenisgeskrifie. Dit word hulle gegun, en ons sal met belangstelling van hulle resultate kennis neem. Maar geen van beide standpunte lok ons aan nie; ons wil die Skrif liewer onbevange nader, nòg gevange in die

* Rede, gehou by die opening van die lesings van die Hervormde Kerk se afdeling van die Teologiese Fakulteit, 28 Februarie 1945.

1) Einführung in das A.T., 1926, 2de druk. bl. 1. 
dwangbuis van die tog ook menslike leersisteme van 'n sogenoemde "gelowige" wetenskap, nòg in die oop hemp van 'n sogenoemde vrye, onbevooroordeelde, onderstellinglose wetenskap. Ons staan skepties teenoor al twee. Die oorlogsjare het geleer hoe die konflikte in die hart en die geestesverwarring in die hoof by "gelowiges" seker nie minder groot is as by hulle wat aan die naam nie heg nie. Ons wil liewer geen standypunt teenoor, selfs nie ten opsigte van die Skrif inneem by ons ondersoek nie. Dis beter dat die Skrif óns standpunt bepaal, ons op ons plek set, hoe ongemaklik die plek dan ook vir ons en ons geliefde opvattinge mag wees.

Ons wil ons graag aan objektiéwe Bybelondersoek wy. Objektief wil sê: deur die objek van ondersoek self en deur hom alleen bepaal, nie deur beskouings oor hom, ditsy .,gelowige" of "ongelowige" nie. Ons wil van die ",selfgetuienis" van die Skrif uitgaan, die ",prima facie” en die dieper selfgetuienis van die Skrif, maar dan nie van die getuienis van een of meer tekswoorde nie en nie deur van die ondersoek van die "selfgetuienis" 'n soort kerklike hofsaak te maak nie; maar ons wil graag die Skrif self laat getuig, deur na al sy uitinge te luister en sy hele verskyning, soos hy daar voor ons lê, op ons te laat inwerk. Wyle Professor KoRFF het dit in sy bespreking van die werk van Dr. G. C. Berkouwer ,Het Probleem der Schriftkritiek," so juis gesê, dat dit primêr nie gaan om 'n min of meer "wetenskaplike" benadering van die Heilige Skrif nie, maar om die erkenning van die werklike toestand waarin die Bybel verkeer. om 'n daad van eenvoudige gehoorsaamheid; en hy noem die standpunt van die letterlike inspirasie: 'n posisie wat ons uit gehoorsaamheid aan die Skrif moes verlaat het. $\left.{ }^{2}\right)$ Wat die Deense Nieutestamenticus FrEDERIK TORM in sy "Hermeneutik des Neuen Testaments" ${ }^{3}$ ) in verband met die verstaan en uitlegging van die Nuwe Testament skryf, geld eweseer by die Ou Testament en by die hele Bybelwetenskap: soos die natuurwetenskaplike navorser hom gehoorsaam moet buig onder wat die ervaringe en eksperimente leer, so moet ook die verklaarder van geestelike verskynsele die selftug oefen om eers na die inhoud van die teks stil te luister. Hy moet met die teks ,,alleen" wees; soos B. JowETT dit uitgedruk het: Die regte ge bruik van die eksegese is, om jou van die eksegese onafhankelik te maak en met die outeur alleen te wees. ${ }^{4}$ ) Dit is wat ToRM die regte "Voraussetzungslosigkeit," die onbevooroordeeldheid in positiewe sin noem: die gewilligheid om die teks op jou te laat inwerk, die oop gemoed teenoor die inwerkingsmoontlikhede van die teks.

2) Sien F. W. A. KonfF, "Gereformeerde" Schriftbeschouwing, Algemeen Weekblad voor Christendom en Cultuur. 15de Jaarg., No. 38, 21 Juli 1939.

3) Göttingen, Vandenhoeck u. Ruprecht, 1930, S. 28, 29, 211.

4) B. JowETT, The Interpretation of Scripture and other Essays, p. 40, aangehaal by Torm, S. 29 A.1. 
In die gees van hierdie uitnemende woorde sou ek ten opsigte van die Bybelondersoek in sy geheel die reël wil stel: die regte, objektiewe Bybelondersoek is om jou van allerlei Bybelbeskouings onafhankelik te maak en met die Bybel alleen te durf wees; en die regte gesteldheid van die Bybelondersoeker is die oop oog en die oop gemoed teenoor die Bybelteks.

Die Bybelteks wat ons die meeste gebruik is die Bybel in vertaling. Wat die Authorised Version vir die Engelse Christenheid beteken, die Lutherbybel vir die Duitse, die Statenvertaling vir die Nederlandse, sal die Afrikaanse Bybelvertaling in meerder of minder mate vir die Afrikaanse Kerke beteken. By die huislike godsdiensoefening en op die kansel, by krankebesoek, by samekomste van kerklike, maatskaplike of nasionale aard sal ons die Afrikaanse Bybelvertaling gebruik. Selfs in ons studeerkamer sal die meeste van ons eers na die vertaalde Bybel gryp, en alleen in besondere gevalle teruggryp na die Bybel in sy oorspronklike taalvorme. Dit lê voor die hand en daarteen is geen beswaar te maak nie. Maar vir wie teologie wil beoefen, is dit wel goed om te bedink dat 'n Bybelvertaling nie die oorspronklike Bybel is nie. Vertaal is altyd tegelyk verklaar, is 'n keuse uit allerlei moontlikhede van vertaling. Prof. JoH. DE GROOT het tereg geskrywe: „Exegese is niet alleen te vinden in commentaren en preeken, maar vooral in vertalingen, zoowel oude als nieuwe; deze bieden alle tekst èn uitleg in eenen, waarbij het verschil met den oorspronkelijken tekst soms even groot is als dat tusschen een tapijt van boven gezien en omgekeerd. Vertalen is naar zijn wezen een vorm van exegetiseeren." ${ }^{\text {; }}$; As Luther in Rom. 3:28 vertaal ,so halten wir nun dafür, dass der Mensch gerecht werde ohne des Gesetzes Werke, allein durch den Glauben," dan is die invoeging van die woordjie ,allein" moontlik heeltemal geregverdig vanuit die woordskikking en sin van die oorspronklike tekswoord sowel as vanuit heel Paulus se regverdigingsleer, maar dit is 'n nadere verklaring, 'n menselike toevoegsel tot die Bybelteks wat sowel die Statenvertalers as die Afrikaanse tereg nie oorgeneem het nie. As die Statenvertalers in Gen. 3:15, die protevangelie of moederbelofte vertaal: ,En Ik zal vijandschap zetten tusschen u en tusschen deze vrouw," dan is die woordjie "deze" 'n verklaring van die vertalers, gerig teen die Roomse opvatting dat met "die vrou" Maria, die moeder van die Heer, bedoeld sou wees; ${ }^{6}$ ) tereg laat die Statenvertalers die uitdrukking slaan op Eva, maar dit is alweer meer dan 'n vertaling, dit is na die letter genome ' $n$ wysiging van die oorspronklike Bybelteks. En as die Afrikaanse Bybelvertalers in Jes. 7:14 die tradi-

5) DR. Joh. DE GROOT, Exegese. Rede uitgesproken na de aanvaarding van het ambt van hoogleeraar aan de Rijksuniversiteit te Utrecht op 2 Nov. 1936. Groningen, 1936, bl. 15. Vgl. ook GrosheIDE, Hermeneutiek, bl. 136 en 244.

6) Sien Prof. Dr. F. W. Grosheme, De Theologie der Statenvertalers; in die bundel: De Statenvertaling 1637-1937. Haarlem, Erven Bohn. 1937, bl. 139. 
sionele vertaling: „Kyk, die maagd sal swanger word" volg, terwyl die oorspronklike Hebreeuse woord ,' $n$ jonge vrou" in die algemeen beteken, dan doen hulle ' $n$ verklarende keuse wat moontlik reg, moontlik ook nie reg is nie. ${ }^{7}$ ) As dieselfde Afrikaanse Bybelvertalers in Hosea 8:9 die Hebreeuse woord vir "liefdebetoninge" of "liefdesgeskenke" vertaal met "onwettige bondgenootskappe," dan gaan hulle wel wat al te ver in die vervanging van vertaling deur verklaring. Ons sou nog kan wys op die verduidelikende invoegsels wat op verskillende plekke in die Afrikaanse vertaling ingelas is, en wat meestal, maar nie altyd nie, ${ }^{8}$ ) deur $n$ ander lettersoort of hakies aangedui word, op die opskrifte bo die hoofstukke, wat ook heel wat exegese bevat ${ }^{9}$ ) - maar die genoemde is voldoende om te bewys dat ons in ons Bybelvertaling heelwat byvoegsels by die oorspronklike Bybelteks het. By die hantering van die belydenis as wetsreglement sou ons die vraag moet stel of hiermee nie oortree is wat in Art. VII van die Nederlandse Geloofsbelydenis staan dat dit ,verbode is om iets by die Woord van God by te voeg" en of ons dan nie in die moeilikheid kom met Art. V waar bely word: ,ons glo sonder enige twyfel alles wat daarin ( $\mathrm{nl}$. in die Heilige Skrif) vervat is." Gaan die inspiratio verbalis en die providentia specialissima ook oor die invoegings van ons Bybelvertalers uit die 20 ste eeu n.C.?

Die teoloog sal altyd weer van die Bybel in sy moedertaal terug gryp na die Bybel in sy oorspronklike taalvorme, dus na die Bybel in Hebreeus (en gedeeltelik Aramees) wat die Ou Testament betref, die Bybel in Grieks wat aangaan die Nuwe Testament. Maar dan kom dadelik die vraag op: na watter teksvorm van die Hebreeuse $\mathrm{Ou}$ Testament en die Griekse Nuwe Testament? Die boekdrukkuns wat 'n geweldige stabilisasie in die teksvorm van enige boek en 'n groot betroubaarheid in die vermenigvuldiging van geskrifte gebring het, is nog geen 5 eeue oud; daarvóór lê 'n baie wisselvallige geskiedenis van Bybelhandskrifte, van wat die Nuwe Testament betref meer as 13 eeue, die hele $\mathrm{Ou}$ Testament meer as 16 eeue en wat die oudste stukke daarvan aangaan byna 3000 jaar. Die aantal handskrifte van die hele $O$. en N.T. of gedeeltes daarvan is legio. Vir die N.T. het ek 'n skatting gesien van ongeveer 4000 , van die waardevolle Griekse vertaling van die O.T. die Septuaginta, wat dikwels 'n ouer lesing bied as die voorhande Hebreeuse handskrifte, alleen reeds $1560 .{ }^{10}$ ) Geen wonder dat die aantal variante tot in die tienduisende loop. Prof. Groenewald

7) ED. KöNIG, Die Messianschen Weissagungen des A. T., Stuttgart 1923, S. 58 verklaar uitdruklik: van 'n bonatuurlike geboorte is in Jes. $7: 14$ nie sprake nie.

8) Bv. nie die woord "verbond" in Hebr. 9:1 nie.

9) Bv. die Messiaanse opvatting in die opskrif bo Ps. 45.

10) A. vaN VeLDHuIZEN, Bijbelsch-Kerkelijk Woordenboek, Het N.T. Groningen 1920, bl. 137. F. KenYon, Our Bible and the Ancient Manuscripts, London. 1939, 4th ed., p. 73 n.l. 
vermeld vir die N.T. alleen reeds die getal 100,000. ${ }^{11}$ ) Van die eerste vyf boeke van die O.T. bevat alleen die Samaritaanse teks (wat Hebreeus as taalvorm het, maar in Samaritaanse letterskrif) ongeveer 6000 plekke waar dit van die gebruiklike Hebreeuse teks verskil. ${ }^{12}$ ) Van die variante in die teks van die N.T. is geskat dat slegs 'n duisendste daarvan substansiële verskil in die teksinhoud maak ${ }^{13}$ ), maar dit beteken dan tog nog dat in ongeveer 100 gevalle die teksinhoud van die N.T. onseker is. ${ }^{13}$ )

Dit maak die geweldige arbeid van die tekskritiek 'n gebiedende eis. Of sal ons maar berus by die sogenoemde Textus Receptus, vir die O.T. dan by die Hebreeuse teks soos deur die Masorete, die Joodse skrifgeleerdes meer dan 500 jaar na Christus, oorgelewer en in die gedrukte Hebreeuse Bybels van Jakob ben Chajjim te Venetië sedert 1524 versprei, en vir die N.T. by die teks wat deur boekdrukkers omstreeks 1500 n.C. op baie gebrekkige handskriftematerieel steunende, uitgegee is? Prof. Groenewald, nadat hy uiteengesit het dat die beste handskrifte van die N.T. onder Gods bestel op perkament geskryf en daarom so goed bewaar is, en dat die wetenskap van die tekskritiek in ons dae sover gevorder is, dat ons vrywel verseker kan wees, dat ons vandag die juiste teks besit en wederom dat ons so dankbaar moet wees dat die oudste handskrifte so wonderlik bewaar gebly bly het, kom dan tot die Textus Receptus, wat hierdie belangrike oudste, welbewaarde handskrifte nog nie gebruik het nie. In plaas van daarop te laat volg 'n betoog ten gunste van die beter Bybelteks soos onder Gods bestel deur die nuwere wetenskap verwerf, skryf hy dan tot my verwondering na aanleiding van die vraag waarvoor die Afrikaanse Bybelvertalers te staan gekom het of hulle die beter teks of die Textus Receptus sou volg: "Toe is die wyse besluit geneem om te bly by die Textus Receptus en daardeur die oortuigings aangaande die teks van die Skrif soos dit leef in die vrome gemoed van die kinders van die Here te eerbiedig." ${ }^{14}$ )

Verstaan ons Prof. Groenewald verkeerd of moet ons aanneem dat hy die konsekwensies van Gods bestel nie aandurf nie? Prof. Groenewald se leermeester, die Gereformeerde Prof. Grosheide van die „Vrye Universiteit” skryf in sy Hermenentiek aldus : „Eindelijk de vraag of misschien aan den Textus Receptus uit geestelijk oogpunt eenige waarde is toe te kennen. ${ }^{15}$ ) Men heeft dit wel betoogd. Immers de T.R. is de tekst geweest der Hervormers, en het was niet buiten

11) E P. Groenewald, Die Nuwe Testament deur die eeue bewaar. Pretoria, 1939. bl. 34 .

12) KeNYON, 1.c., p. 50.

13) KenYoN, l.c., p. 23 n.1. (na HorT); Groenewald, t.a.p.

13a) GROSHEIDE noem 'n 7-tal wat groot moeilikhede oplewer. Hermeneutiek bl. 153

14) Groenewald, t.a.p. bl. 45 (sien vir die gang van sy betoog bl. 31, 36, 41).

15) Let wel: ,uit geestelijk oogpunt"! PROF. GROSHEIDE spreek hier nie slegs van: .uit wetenschappelijk oogpunt" nie, maar "uit geestelijk oogpunt." 
Gods voorzienig bestel, dat die tekst destijds gold en ten grondslag is gelegd aan de Bijbelvertalingen van de Kerken der Reformatie. We kunnen zulke opmerkingen niet van gewicht achten. In de eerste plaats is de T.R. niet zulk een eenheid als men vroeger meende. In de tweede plaats was het ook Gods voorzienig bestel, dat eerst in de negentiende eeuw, de eeuw der historische nauwkeurigheid, de oudste en algemeen voor de beste gehouden handschriften òf bekend, òf toegankelijk òf beter gelezen werden. En eindelijk is het ook op dit terrein niet geraden iets tegen het geweten te doen." ${ }^{16}$ ) Die Gereformeerde Prof. A. NoordtzIJ laat 'n ewe ernstige waarskuwing teen die gebruik van die Textus Receptus hoor in sy besonder oriënterende artikel „De tekst van het Oude Testament en zijn geschiedenis" in die Gereformeerde „Bijbelsch Handboek” by die Gereformeerde uitgewer Kok in Kampen in 1935 verskene, as hy wys op die eis dat "door nauwkeurige bestudeering van de gegevens, welke de Heere, onze God, ter correctie van den Hebreeuwsche tekst te onzer beschikking heeft gesteld, er naar gestaan (mỏet) worden de corruptieve elementen van de tekst te verwijderen.... De breede kring van de gemeente van Jezus Christus, die van de in het Oude Testament tot haar komende geestelijke schatten slechts kan genieten door een vertaling, heeft er het recht op, dat zij, door wier bemiddeling die vertaling tot haar komt, in geen enkel opzicht aan de waarheid te kort doen .... De gemeente van Jezus Christus, die in dezen van anderer arbeid afhankelijk is, heeft er het recht op, dat ook, ja vooral in dezen volstrekte eerlijkheid tegenover haar word betracht" (t.a.p. bl. 325.) ${ }^{17}$ )

Tereg spreek Noordtzij dan ook van ,de onafwijsbare taak, om achter den ons door het Jodendom overgeleverden Hebreeuwschen tekst door te dringen tot een ouderen tekst, die dichter bij den oorspronkelijken staat en aan minder gebreken mank gaat." ${ }^{18}$ ) Hierby kan ongetwyfeld die Septuaginta groot dienste bewys, waar sy vernaamste handskrifte soveel as 6 eeue ouer is as die voorhande Hebreeuse handskrifte, en ons sedert die vonds van die Chester-Beatty papyri 'n teksvorm het wat nog een of twee eeue verder teruggaan. NoordtziJ beklemtoon baie sterk die hoë gewig van die Septuaginta vir die rekonstruksie van die Hebreeuse teks. .Wie dus door zijn tekstkritischen arbeid mede wil werken tot het benaderen van een meer betrouwbaren

16) Dr. F. W. Groshejde, Hermenentiek ten dienste van het Nieuwe Testament. Amsterdam, 1929, bl. 160.

16) Dr. F. W. Grosherde, Hermeneutiek ten dienste van het Nieuwe Testament. 1i) In die lig van hierdie onverbloemde uitsprake van erkend Gereformeerde geleerdes, is dit vir my nog altyd ewe verwonderlik dat die Gereformeerde Professore J. D. en S. Du ToIT saam met PROF. Groenewald in Afrikaanse Bybelverklaring wou gee, waarby van die Afrikaanse Bybelvertaling wat steun op die Textus Receptus uitgegaan sou word. In hierdie opsig het hulle intussen na deur my ingebragte besware van die ,"dwaling huns weegs" teruggekeer.

18) t.a.p. bl. 323 . 
tekst dan dien, welken de Masora ons biedt, mag niet, gelijk nog maar al te dikwijls geschiedt, den Masoretischen Tekst beschouwen als veritas hebraica.... maar moet althans den tekst dien de Septuaginta en de Vulgaat bieden, als im Grossen und Ganzen gelijkwaardig erkennen." ${ }^{19}$ ). Noordtzlj wys verder op die groot waarde van die tekskritiese apparaat in R. Kittel's Biblia Hebraica en sê: „Haar groote waarde berust in de critische noten.... Wie in onze dagen het O.T. in den grondtekst wil bestuderen, kan de biblia Kitteliana niet missen." ${ }^{20}$ )

Persoonlik het ek die hulp nagegaan wat die Septuaginta by die herstel van die teks van die boeke van Samuel verleen, en dit het my by ' $n$ konservatiewe skatting geblyk dat daar op die ruim 1500 verse van die twee boeke ongeveer 220 gevalle is waar die Septuaginta ' $n$ in die oog lopend betere teks het, wat dus beteken dat minstens in elke 7 verse daar een is, wat ons met daardie hulp in sy meer oorspronklike vorm kan herstel. Dit was nogal merkwaardig om te vind dat in vies gevalle die Afrikaanse Bybelvertalers blykbaar ook nie sonder die Septuagintalesing kon klaarkom nie. ${ }^{21}$ )

Tekskritiek is algemeen ook in die Gereformeerde kamp of soos KUYPER sou sê: .,op het erf der palingenesie" as onmisbare, integrerende deel van die Bybelondersoek erken.."2) Ons sou weer kan vra: kom ons nie deur die beoefening van kritiek aan die teks van die Bybel in konflik met die Belydenis, met genoemde artikels V en VII en met die leerstuk van die onfeilbaarheid of feilloosheid van die Skrif nie? Na die letter seer seker. Prof. H. H. Kuyper kan wel poneer ,dat wij wel een onfeilbaren bijbel hebben, maar niet een onfeilbaren tekst," ${ }^{23}$ ) maar is dit nie 'n skolastieke onderskeiding wat, na die geliefde Gereformeerde uitdrukking, .,geen hout snijdt"? Hoe kan mens die Bybelteks van die Bybel skei? Tekskritiek is maar nie 'n werk aan die uitwendige vorm van die Skrif nie, maar aan die Skrif soos hy daar voor ons lê self. Die onfeilbare bybel van Prof. KuYPER is 'n hipotetiese grootheid, wat in die lug, die dogmatiese lug hang. 'n Nugter man sou met 'n variasie op Jacobus kon vra: „Wat baat dit, broeder, as iemand sê dat hy 'n onfeilbare bybel het, maar hy het nie 'n onfeilbare teks nie. Toon my u onfeilbare bybel uit u teks vol feile!" Glo óns dan nie in die onfeilbaarheid van die Heilige Skrif nie? Ja seker, en dit nog wel in die onfeilbaarheid van die Skrif soos hy hier voor ons lê, in die onfeilbaarheid van die Skrif vol feile. Maar nie in die sin van Prof. KuYper en so baie van sy mede-dogmatici nie.

19) t.a.p. bl. 325 .

20) t.a.p. bl. 303 v.

21) I Sam. 12:6, II $17: 13,27 v$., 18:26.

22) Sien A. KuYYPER, Encyclopaedie der Heilige Godgeleerdheid. dl. III, Amsterdam 1894, bl. 65-78. Ook Berkouwer, Het Probleem der Schriftkritiek, bl. 301-314.

23) Sien sitaat uit De Heraut van 20 Febr. 1921, by BERKOUWER, bl. 304 n. 14. 
wat almal lê onder die ban van die letterlike inspirasiegeloof en van die juridiese konfessiebeskouing en konfessiepraktyk. Ons glo in die H. Skrif as die onfeilbare gids na die lewe; of om met die woorde van die Belydenis te spreek: „dat God Homself nog duideliker en meer volkome (as deur die skepping en onderhouding en regering van die hele wêreld) bekend maak deur sy heilige en Goddelike Woord, soveel naamlik as wat ons nodig het in hierdie lewe, tot sy eer en die saligheid van wie aan Hom behoort" (Art. II) .Ons glo dat hierdie heilige Skrif die wil van God volkomenlik bevat, en dat alles wat die mens moet glo tot saligheid, daarin genoegsaam geleer word" (Art. VII). Ons neem ook ,al hierdie boeke aan as heilig en kanoniek om ons geloof daarna te rig, daarop te grond en daarmee te bevestig" (Art. V). In hierdie sin glo ons ",sonder enige twyfel alles wat daarin vervat is" en in hierdie sin erken ons dat "dit verbode is om iets by die Woord van God by te voeg of daarvan weg te laat." En dit is vir ons 'n aanbiddelik wonder dat God deur sy Skrif vol feile ons so onfeilbaar op die weg van saligheid en van Godsverheerliking lei. Maar ons wil nie ' $n$ andere Skrif poneer as wat ons deur Gods bestel in hande gegee is nie.

Tekskritiek is nie maar uitwendige kritiek nie. Dit gryp veel verder en dieper as ' $n$ vergelyking en telling van die verskillende handskrifte. Ons wil tog nie tekskritiek oefen op die wyse wat in die Talmoed meegedeel word nie waarvolgens van drie handskrifte wat in die voorhof van die tempel bewaar geword het, by afwykende lesinge telkens dié van die meerderheid aangeneem is! ${ }^{2.1}$ ) Regte tekskritiek is nie sonder eksegese te beoefen nie; dit moet die variante wik en weeg na die groter sinsverband. Hier blyk weer hoeseer die regte Bybelondersoek ' $n$ organiese eenheid is.

Maar waar die handskrifte geen verskil in teks vertoon nie, is ons daar seker die oorspronklike Bybelteks voor ons te hê? Ook dan nie, want ons kom dikwels voor heeltemal onvertaalbare verse of versgedeeltes te staan. Dan moet ' $\mathrm{n}$ ander vorm van kritiek, die sogenoemde konjekturaal-kritiek ingeroep en beoefen word. Dit is nogal opmerklik dat van Gereformeerde kant die reg en plig van konjekturaal-kritiek so gul toegegee word. A. KuYPER sê in sy Encyclopaedie: „Gemis aan gegevens (hy bedoel handskriftelike gegewens) dwingt soms tot gissen... Op zichzelf mag nooit beweerd, dat het theologisch karakter dezer studiën (hy bedoel die bestudering van die Bybelteks) de conjectuur, als zoodanig, eens vooral buiten hun kader zouden sluiten. Uit een bedorven tekst kan scherpzinnigheid soms den oorspronkelijken tekst met zulk een evidentie te voorschijn brengen, dat ge er de waarheid onmiddelijk van inziet... Het ware irrationeel de coniec-

24) Sien W. Robertson Smith. Het Oude Testament in de Joodsche Kerk, vert. dr. C. Beets. Utrecht, 1882, bl. 68 en 344. En ook Noordtzi, t.a.p. bl. 308. 
tuur alszoodanig bij de tekstkritiek der Heilige Schrift te willen uitsluiten. Ze kan waarheid vinden en bezit deswege een onbetwisbaar bestaandsrecht." ${ }^{25}$ ) In hierdie nogal rasionalistiese betoog word die deur tot ingrype in die Bybelteks, dus tot inwendige kritiek oopgeset. Wel word gesê dat eers vas moet staan dat die teks bederf is. maar hoe is dit moontlik om teksbederf vas te stel sonder om die teks aan 'n kritiese ondersoek te onderwerp? GrosheIDE laat tereg die konjekturaal-kritiek in die skema van Bybelondersoek volg op die eksegese. Sy skema is: tekskritiek, laere of grammaties-historiese eksegese, konjekturaal-kritiek, hoëre eksegese en hy sê: ..De tekstkritiek kan via de exegese leiden tot conjecturaal-kritiek." ${ }^{26}$ ) Vlak hieraan vooraf gaan die merkwaardige konstateringe: „Men kan wel de kritiek op de overlevering (blykbaar is bedoel die ondersoek van handskrifte en ander uitwendige getuienisse) stellen naast die van de Schrift. Maar in de practijk loopen beide in elkander over." $\mathrm{Na}$ my mening loop hulle nie alleen in die praktyk, maar ook in die teorie van Bybelondersoek in elkaar oor. Al hierdie funksies van Bybelondersoek staan in organiese verband met mekaar.

Sonder konjekturaal-kritiek sal niemand dit reg kry om bv. die boek van die profesieë van Hosea verstaanbaar te vertaal. ${ }^{27}$ ) Die Afrikaanse Bybelvertalers maak ook 'n enkele maal daarvan gebruik; bv. waar hulle in Hosea 9:4 die woordjies ,"hulle spys" invoeg, in II Sam. 21:16 die woordjie "swaard" en in 22:3 in pleks van "God van my rots" lees „God is my rots."

Baie nou verwant met die konjekturaal-kritiek is die aanneem van foute in die Bybelteks, ook waar daar generlei uitwendige, handskriftelike teksgetuie is wat op verskil van lesing wys en waar die tekswoorde ook glad nie moeilikhede vir die vertaling gee nie. In die eerste vers van die boek Daniel lees alle handskrifte "In die derde jaar van die regering van Jojakim, die koning van Juda, het Nebukadnéser, die koning van Babel na Jerusalem gekom, en dit beleër." Daar is generlei moeilikheid in die vertaling van die vers nie. Tog vind die Gereformeerde Prof. G. C. Aalders hier 'n fout in die teks. ${ }^{28}$ ) Waarom? Omdat andere gegewens in die Bybel nie met hierdie veronderstelde veldtog van Nebukadneser in die derde jaar van Jojakim in ooreenstemming gebring kan word nie. Prof. Aalders stel voor om inpleks van die derde jaar te lees die sesde jaar. Wat is dit anders as inwen-

25) t.a.p. b. 71 en 72. Vgl. ook Groshejde, Hermeneutiek, bl. 179 en Berkouwep Probleem, bl. 310-313.

26) t.a.p. bl. 105 n. 14 .

27) Ek verwys deskundiges na Hosea $3: 3,4: 4,19,5: 2$ en $11,6: 5,7: 6,12$, $8: 5,9: 1,4,6,10: 11,11: 3,4,5,12: 9,12,13: 1,14: 3$.

28) Dr. G. Ch. Aalders. Het Boek Daniël, in Korte Verklaring der H. Schrifi Kampen, 1928, bl. 42-45. 
dige Bybelkritiek? ${ }^{29}$ ) Dieselfde Prof. Aalders skrap in Jeremia die hele vers Hfst. 3:18, die profesie oor die gesamentlike terugkeer van Juda en Israel na die land van die vaders, en dit enkel op inwendigkritiese gronde. Hy verwyder die vers eenvoudig uit die teks as 'n kanttekening uit die tyd van die later Jodedom „om aan te geven hoe ook hier de toenmaals sterk levende verwachting van een wederkeer der Joden uit alle landstreken der wereld grond had in de profetie." ${ }^{\prime \prime}$ ) Dit is ' $n$ suiwer kritiese redenering. Selfs die teorie van die inspirasie van ook die later toevoegsels aan die Bybelteks kom hier sterk in die gedrang.

Daar is heel wat skrappinge van hierdie aard in die Jeremiaverklaring van Prof. Aalders. So bv. van H. 10:11 die Aramese vers. wat tog wel enigsins geringskattend 'n ,,later inschuifsel" genoem word. Ook 15:13v. word geskrap, sonder handskriftelike steun. Eweso 51: 15-19 hoewel die skrywer self erken dat hierdie verse in alle handskrifte en ou vertalinge voorkom (t.a.p. bl. 287). Die verse is volgens die skrywer "machinaal, gedachtenloos" uit H. 10 oorgeneem. In H. 38:5 skrap Aalders 'n gedeelte van die teks nl. die woorde: ,en hulle het Jeremia met toue laat afsak," en dit op suiwer inwendige gronde. ${ }^{31}$ )

Dr. A. Kuyper noem hierdie soort kritiek "de hoogere kritiek." „Zeer dikwijls" skryf KuYPER, ,.(zal het) onmogelijk blijken, alleen op grond van wat het (critische) apparaat ons biedt, tot een eenigzins gemotiveerd oordeel over den vermoedelijken tekst van het autographon te geraken. Vandaar dat de hoogere kritiek, die haar maatstaf aan den gedachtengang van den schrijver ontleent, niet slechts de lagere critiek, die op het critische apparaat rust, steeds heeft te vergezellen, maar ook, waar het critische apparaat in den steek laat, ten slotte den doorslag moet geven." ${ }^{32}$ )

Die naam ",hoëre kritiek" het by baie Christene 'n slegte klank, netsoos trouens die woord "kritiek" alleen reeds. Ons het egter reeds gesien dat Gereformeerde teoloë sonder enige beswaar van tekskritiek en konjekturaal-kritiek ten opsigte van die Bybelteks spreek en gebruik

29) PROF. S. Du Tolt sê dat daar by die uitbou van die Gereformeerde Skrifbeskouing "nie aangeneem word dat daar foute in die Skrif is nie" (sien: 'n Nuwe Fase in die Stryd om die O.T., Potchefstroom, 1936, bl. 18). Hy bedoel hier seker die hipotetiese Skrif van Prof. H. H. KuYPER, wat so maklik inkom om moeilikhede te ontduik.

30) Sien sy: De Profeet Jeremia. Korte Verklaring, Kampen 1923 bl. 23 n. 2. Dis nogal interessant om op te merk dat Dr. VAN RAVENSTEIIN in sy Jeremiaverklaring in Tekst en Uitleg, 1925, die vers behou.

31) Oor die algemeen is Aalders nogal krities teenoor die Masoretiese Teks en volg hy menigmaal die Septuaginta, vgl. sy verklaring by $25: 13,24,26,27: 1,30: 7$. $40: 4,41: 7,9,42: 1,43: 10,12,45: 4,51: 64,52: 20$. Hy ag die plasing van die Profesieë teen die Volke H. 46 vv. soos in die Septuaginta midde in H. 25 oorspronkliker, voel veel vir die skrapping van $H$. 33:17-26 en volg die ,algemeen aanvaarde tekstwijziging" in $41: 6$.

32) Vgl. Encyclopaedie III, bl. 77. 
maak. GrosheIDE erken in sy Hermeneutiek: „Wetenschap zonder kritiek is onbestaanbaar. Het eigenaardige der wetenschap is immers juist, dat ze vraagt naar grond en oorsprong der dingen, naar wezen en samenhang. Ze is werkzaamheid in hoofdzaak van het menschelijk verstand en het verstand doet zijn werk al schiftend en oordeelend. Zoo kan ook de wetenschap van het Nieuwe Testament niet zonder kritiek (bl. 81). De wetenschap heeft altijd te ordenen, en ordenen kan ze niet, zonder te schiften, dat is te oordeelen" (bl. 103 aant. 1). Selfs vir die woord Skrifkritiek skrik Grosheide nie terug nie en met sy definisie van wat ware Skrifkritiek is, sal menig sogenoemde criticus dit van harte eens wees: .Wetenschappelijk is die Schriftkritiek, die de Schrift aanvaardt, gelijk ze is en haar haar eigen beoordeelaarster laat zijn" (bl. 82). Trouens reeds DR. A. KuYper was nie so bevrees as vele van sy navolgers vir kritiese en selfs histories-kritiese ondersoek nie. Hy skryf in sy Encyclopaedie deel III bl. 51: „Ongeoorloofd is het, aan alle historisch-critisch ondersoek naar den oorsprong. de samenstelling en de latere redactie van de geschriften des Bijbels, enkel wijl de resultaten van dit ondersoek niet met zekere overgeleverde meeningen overeen komen, den pas te willen afsnijden."

As Grosheide laere en hoëre eksegese onderskei en KuYper laere en hoëre kritiek, dan is aan hierdie woordgebruik seker nie te ernstige besware verbonde nie. Of dit 'n baie duidelike onderskeiding is en of dit in die praktyk van die Bybelondersoek uit mekaar te hou is, is ' $n$ andei kwessie. Onder ",laere kritiek" word gewoonlik die tekskritiek verstaan, onder "hoëre" die outentisiteitsvrae of nog beter soos KuYPER dit hierbo omskryf: die ondersoek na die oorsprong, samestelling en latere redaksie van die geskrifte. Maar waartoe behoor dan die konjekturaal-kritiek en die inwendige kritiek soos bv. deur Aalders beoefen, wat albei baie nou met eksegese en egtheidsvrae samehang?

In pleks van die onderskeiding laere en hoëre kritiek vind mens ook dié van tekskritiek en kritiek van die inhoud - maar hoe kan teks en inhoud van ' $n$ geskrif geskei word? Uitwendige en inwendige kritiek is ' $n$ ander manier van benaming; as die juis is, dan hoor die konjekturaal-kritiek en die vanuit die inhoud, seker by die tweede afdeling, die hoëre kritiek. Die tekskritiek is ook wel diplomatiese kritiek, di. kritiek van die oorkondes genoem, of partiaal-kritiek naas die hoëre as totaalkritiek. LuDWIG PRELLer onderskei by die argeologiese ondersoek; uitwendige, konjekturaal- en konstitutiewe kritiek. ${ }^{3{ }^{3}}$ )

In die wetenskappe van Filologie en Geskiedvorsing is die noue samehang van uitlegging en kritiek algemeen erken en aanvaar. In die

ss) Sien vir hierdie verskillende benaminge JOACHIM WACH, Das Verstehen. Grundzüge einer Geschichte der hermeneutischer Theorie im 19. Jahrhundert. Tübingen, I 1926, II 1929. III 1933. Sachregister s.v. Kritik. Oor L. Preller sien dl. III bl. 313 vv. 
3 dele van die degelike boek van JoAchim Wach, Das Verstehen, lê die voorbeelde voor 't grype. Sowel Ast as Fr. A. Wolf as SchleierMACHER beklemtoon die noue verwantskap, en saamhorigheid van hermeneutiek of uitlegging en kritiek. Albei veronderstel mekaar. GERMAR spreek van die wisselwerking waarin die verskillende interpretasie-middele met mekaar staan, hy noem dit „Panharmonie." C. G. WILKE eis in sy Hermeneutiek van die N.T. die organiese samehang van die afsonderlike dele van die hermeneutiese leersisteem.

WACH self noem by die bespreking van die werk van $B$. C. NIEBUHR die kritiek die suster en onafskeidelike begeleidster van die hermeneutiek en skryf: „Mens weet hoe op alle gebiede wat 'n teorie van die inspirasie laat ontstaan het, steeds kritiek en hermeneutiek in mekaar gryp." BERNHARDY spreek van 'n aanvulling (Ergänzung) en wisselwerking tussen beide. REICHARDT noem die kritiek 'n moment van die hermeneutiek. Fr. W. Ritsch skryf dat die skynbaar so neterogene filologiese leervakke hulle tot die eenheid van $n$ organiese geheel laat saamknoop as ' $n$ integrerende wetenskap. Hy spreek van die verhouding van hermeneutiek en kritiek as 'n sirkel. ${ }^{34}$ ) Ook TORM in sy genoemde Nieutestamentiese hermeneutiek vermeld die hermeneutiese sirkel en sê: die vraag van die verstaan gryp in menig opsig sodanig oor op die gebied van die ondersoekinge oor die outeur van 'n geskrif, tyd en plek van vervaardiging, leserskring waarvoor bestemd, voorkome van interpolasies e.d. dat 'n volledige skeiding nie moontlik is nie. Die verstaan kan sonder ingrype van die historiese kritiek nie ten einde gebring word nie. Die verstaan is altyd 'n organiese eenheid. ${ }^{38}$ )

Teenoor hierdie belangrike reeks van getuie uit die nuwere filologiese, historiese en teologiese wetenskap, die wetenskap uit wat GROSHEIDE so waarderend noem ,,die eeu van historiese noukeurigheid," klink dit wel 'n weinig oormoedig as die dogmaticus BERKOUWER spreek van ",den totaal verschillenden aard" van tekskritiek en hoëre kritiek (wat hy prejudicerend Skrifkritiek noem). 'n Naklank hiervan, maar dan in meer populêre beeldspraak, hoor ons in 'n voetnoot by die artikel van Prof. S. Du TorT oor "Opgrawings-wetenskap en Ou Testament" waar hy sê: ,dat daar 'n hemelsbreë verskil is tussen tekskritiek en Skrifkritiek." Baie beskeidener spreek GROSHEIDE, die ervare vakman, oor ,het probleem: zijn tekstkritiek en hoogere kritiek volkomen te scheiden?" ${ }^{36}$ )

In die praktyk van objektiewe Bybelondersoek blyk keer op keer dat tekskritiese kwessies en kwessies van outeurskap, outentisiteit, in-

34) Sien WACH, Das Verstehen I S. 87, 110, II S. 211, 221, 340 A 2, III S. 55, $90,257,271,279$.

35) Sien Torm t.a.p. bl. 129, 176, 177, 179, ook bl. 5, 14, 21

36) Berkourwer, t.a.p. bl. 313. S. DU TolT in die versamelwerk: Koers in die Krisis, dl. II. 1940 , bl. 75 in voetnoot. Grosheide, Hermeneutiek, bl. 229 r. 6. 
tegriteit, en agtergrond van 'n geskrif in mekaar oorgryp. As in die Psalmboek 4 Psalms wat in die Masoretiese teks op naam van Dawid en een wat op naam van Salomo staan, in Griekse en selfs Hebreeuse handskrifte nie aan hom toegeskryf word nie, as daarenteen 14 Psalms wat in die Hebreeuse teks nie aan Dawid toegeken word nie in die Septuaginta wel sy naam dra en 4 Psalms wat in die Septuagintit aan Haggai, en Sagaria toegeken word in die Hebreeus sulke opskrifte nie dra nie, lei dan nie die tekskritiese getuienis oor tot die stel van die kwessies van outeurskap en outentisiteit nie, en is dit dan nie 'n redelike gevolg van hierdie bevind van sake dat meer op die inhoud as op die opskrif van 'n Psalm gelet sal moet word vir die bepaling van sy outeur en ouderdom nie? ${ }^{37}$ )

As dan bv. in Psalms wat in die Masoretiese en Septuaginta-teks albei aan Dawid toegeken word, die inhoud teen ' $n$ Dawidiese outeurskap pleit (bv. deur vermelding van die tempel, wat immers in Dawid se dae nog nie bestaan het nie - so Ps. 5:8, 27:4 e.e. - of deurdat die digter hom duidelik van Dawid onderskei, soos Ps. 144:10 v., ook wel 122:5 en 9) is dit dan aanranding van die Woord van God as ons liewer na die inhoud as na die opskrif gaan?

As in Jeremia 27 waar beskryf word hoe die profeet aan koning Sedekia en die gesante van naburige state onderwerping aan die koning van Babel moet aansê, dit vreemd klink dat die profeet tegelyk die opheffing van daardie oordeel verkondig, en selfs aan die profeet die onvervulde profesie in die mond gelê word dat die twee koperpilare van voor die tempelgebou en die kopersee en die 12 afspoelwaentjies eenmaal uit Babel sal terugkeer (maar inderdaad is hulle deur die Babiloniërs stukkend gebreek en die stukke koper na Babel gevoer). dan laat die inhoud van hierdie hoofstuk op sigself reeds egtheidsvrae opkom. As dit dan nou blyk dat die gedeeltes wat moeilikheid gee in die Septuaginta-teks ontbreek, gryp dan tekskritiek en hoëre kritiek nie inmekaar nie? Waar is dan die hemelsbreë afstand wat tussen hierdie twee organe van dieselfde organisme geponeer word?

Hierdie voorbeelde word by noukeurige Bybelondersoek gedurig vermeerder en kan in die brede uitgewerk word. ${ }^{38}$ ) Ons het reeds gesien hoe 'n bekwame Gereformeerde eksegeet soos Prof. Aalders meermale in verband met versgedeeltes of hele verse of selfs perikope van die teks van die boek Jeremia die egtheidsvrae stel en tot skrapping oorgaan. Hoe dan ook Prof. S. DU Torr in die genoemde artikel kan beweer en nog wel kursief kan laat druk dat die Gereformeerde ,in

s7) Sien die betrokke teksuitgawes en kritiese apparaat by Ps. 122, 124, 131, 133, 127. bv Ps. 33, 43, 67, 71, 91, 93-99, 104, 137 en by Ps. 146-8 (in die Septuaginta 4 afsonderlike Psalms).

${ }^{28)}$ Sien bv. W. RoBertSon Smith, Het O.T. in de Joodsche Kerk, bl. 92-114 of die corspr. Engelse uitgawe The O.T. in the Jewish Church, London, 1926. 3d. ed. p. $90-125$. 
die kanonieke boeke geen onegte stukke kan aanvaar nie" kan ek alleen uit jeugdige onbekendheid met die Gereformeerde eksegetiese literatuur verklaar.

Die Gereformeerde eksegetiese praktyk van die laaste twintig jaar vertoon ' $n$ verrassende openheid vir kritiese vraagstellinge en kritiese oplossinge. Prof. Aalders neem aan dat ongeveer een vyfde van die tradisioneel genoemde Boeke van Moses nie van Moses afkomstig is nie en vind dat die Nieutestamentiese spraakgebruik aangaande: „die boek" of ,,boeke" of ,die wet van Moses" of van "Moses" sonder meer by verwysinge na die $\mathrm{Ou}$ Testament vir die vraag aangaande die Mosaiese outeurskap van die Pentateuch geen dwingende bewyskrag het nie. ${ }^{39}$ )

Dr. A. Noordtzij en Dr. W. H. Gispen beklemtoon sterk dat Deuteronomium 'n aparte wetboek naas die Sinaïtiese bondsboek is, en wys uitdruklik op die belangrike onderskeid tussen hierdie twee. Hulle skryf dan die merkwaardige woorde, wat sterk na die kritiese beskouing ruik: „De ,woorden van het Verbond' zijn geen woorden des Heeren in dezelfde mate als dit met die van het Sinaïetisch bondsboek het geval is. Ze worden uitdrukkelijk gegeven als woorden van Mozes... Ook in taal en stijl staat Deuteronomium in het geheel van den Peutateuch ten eenenmale apart.... Onder de profeten is het vooral Jeremia, die in taal en stijl den invloed daarvan heeft ondergaan." ${ }^{40}$ )

Prof. Ridderbos het nog wel besware teen die aanvaarding van 'n Deutero-Jesaja, maar sê tog: ,het is niet noodig dit Jesajaansch auteurschap op te vatten in dezen $z$ in, dat deze hoofdstukken van a tot $z$ door Jesaja moeten zijn geschreven." Veral by die hoofstukke 56-66 ag hy toevoegsels nie buitegeslote nie en wys op ,.die plaatsen, waar de profetie haar historisch uitgangspunt in den tijd na de ballingschap schijnt te nemen." ${ }^{+1}$ )

Dat „Die Klaagliedere van Jeremia" nie van die profeet Jeremia afkomstig is nie, is blykbaar reeds 'n uitgemaakte saak in die nuwere Gereformeerde eksegese. ${ }^{42}$ )

Die boek Jona kan nie uit die tyd van die in II Kon. 14:25 genoemde profeet wees nie. "De taal wijst heel duidelijk naar den tijd van de ballingschap." Dit het blykbaar sy boodskap eers vir die dae van Esra en Nehemia gehad, meen NoordTZIJ en GISPEN. ${ }^{43}$ )

39) Sien sy verklaring van Genesis in die Korte Verklaring der H.S. I, 1933 bl. 35.

40) Sien hulle artikel oor „De Inhoud van het Oude Testament” in „Bijbelsch Handboek" I, Kampen, 1935, bl. 439.

11) Dr. J. Ridderbos in Christelijke Encyclopaedie onder red. van DR. F. W. GroshejDE e.a.. Kampen, 3de dl., s.j. (die geheel het in die jare 1925-1931 verskyn), bl. 149 v.

42) Vgl. Aalders, De Klaagliederen, Korte Verklaring, Kampen, 1925, bl. 10-13 en ook NoordtziJ en GiSPEN in Bijbelsch Handboek, bl. 522.

43) Bijbelsch Handboek, b?. 478. 
As in die Psalmboek 'n Psalm waarvan die opskrif Asaf as digter noem, na sy inhoud nie pas op die tyd van Dawid of Salomo waarin Asaf geleef het nie, dan ,kan (het opschrift) gevoegelijk (zoo) worden verklaard, dat de Psalm behoorde tot een bundel liederen der Asafieten" d.w.s. van die sangersgilde na Asaf genoem uit later eeue, meen dieselfde geleerdes.

By Spreuke is daar volgens hulle prinsipieel geen beswaar te maak teen die stelling, dat nog meer stukke in die boek as $H$. 30:1 vv. en $31: 1 \mathrm{vv}$. uitlandse wysheid sou bevat. ${ }^{44}$ )

By die bespreking van Job word die merkwaardige „entwicklungsgeschichtliche" argument gebruik "dat men een dergelijk geweldig kunstwerk niet aan het begin van Israels litteraire ontwikkeling kan verwachten." $\$ 5$ )

Die boek Prediker word nie meer as van Salomo afkomstig beskou nie. Die Gereformeerde eksegete van Gelderen, Aalders, NoordtZIJ en GISPEN is dit hieroor eens, nieteenstaande die boek self in $\mathrm{H}$. $1: 1$ en 12 sê: "Die woorde van die Prediker, die seun van Dawid, die koning in Jerusalem" en „Ek, Prediker, was koning oor Israel in Jerusalem." PROF. van GELDEREN probeer aan die end van die eerste deeltjie van sy verklaring van I Koninge die krag van hierdie nogal duidelike woorde te ontsenu. ${ }^{16}$ ) Die argumente by NoordtziJ en GISPEN is die gewone hoër-kritiese, aan taal en inhoud ontleen. ${ }^{17}$ ). Merkwaardig is in hierdie verband die volgorde van behandeling van die boeke van die Ou Testament in die artikel van Noordtzij en Gispen waarby Klaagliedere en Prediker die ry besluit. Ewe kenmerkend is dat AaLders in dieselfde Bijbelsch Handboek in sy artikel "Geschiedenis van de Oudtestamentische Godsopenbaring" hierdie geskiedenis besluit met die behandeling van Ester, Prediker en Kronieke. waarby Prediker dus onder die jongste na-exiliese boeke verskyn (bl. 236).

Ten slotte vermeld ons nog dat, al wil die Gereformeerde Bijbelsch Handboek nog nie van 'n Deutero-Jesaja weet nie, 'n Deutero-Sagarja wel aanvaar word. By die tweede gedeelte van die boek Sagarja sê NooRdTZIJ en Gispen: "In een geheel andere wereld (dan de eerste 8 hoofdstukken) brengt ons de tweede helft van het naar Zacharia genoemde boek. Hier is geen sprake meer van Zerubbabel en Jozua, ook niet van het herbouwen van den tempel. Ook vinden we hier geen dateering; zelfs geen aanduiding van den profeet, aan wien we deze hoofdstukken te danken hebben. Boven 9:1 en 12:1 staat niet anders dan ,Godspraak'." Dan vermeld die skrywers verskillende moontlike daterings, sonder daaronder 'n eie keuse te doen. Die toepassing van

44) t.a.p. bl. 514 .

45) t.a.p. bl. 521 .

46) Korte Verklaring, De Boeken der Koningen, I, 1926, bl. 241 v.

17) Bijbelsch Handboek, bl. 522 v.v. 
hierdie kritiese betoog op ander gedeeltes van die Skrif sou tot verrassende resultate lei. .

Ons lees nog eenmaal die onderstreepte verklaring van $\mathrm{P}_{\mathrm{ROF}} \mathrm{S}$. Du ToIr „,die Gereformeerde sal in die kanonieke boeke geen onegte stukke kan aanvaar nie" en vryf ons oë uit. Ons sou ook wil vra aan die belydenis-belyers, wat die Belydenisartikels as artikels van ' $n$ geloofswetboek wil hanteer: Hoe sal dit die bogenoemde Gereformeerde eksegete vergaan as hulle bewerings met die bewoordings van Art. IV van die Nederlandse Geloofsbelyydenis gekonfronteer word? Hier tog word bely dat ,die getal van die kanonieke boeke in die Kerk van God is.... die vyf boeke van Moses... drie boeke van Salomo, die twaalf kleine profete... die veertien briewe van die apostel Paulus". Die nuwere Gereformeerde eksegese ontsê een vyfde van die inhoud van die boeke van Moses aan Moses en lyk nogal krities gestem ten opsigte van die outeurskap van Deuteronomium, dit tel nie meer drie boeke van Salomo nie maar twee, nie meer twaalf kleine profete nie, maar minstens dertien, nie meer veertien briewe van die apostel Paulus nie maar dertien (want die Brief aan die Hebreërs word deur die nuwere Greformeerde eksegete algemeen aan Paulus ontsê). ${ }^{+8}$ )

Volgens die huidige stand van die Gereformeerde eksegese sou Art. IV moet lui : ,die vyf boeke van Moses en van ander skrywers... die twee boeke van Salomo... die dertien of meer kleine profete... die dertien briewe van Paulus." Tog is my nie bekend dat een van die genoemde Gereformeerde eksegete ook maar een gravamen teen die bewoordings van Art. IV by hulle kerke ingedien het nie, laat staan die vier gravamina wat hulle sou kan en volgens die juridieskonfessionele standpunt moes ingedien het. Dit tref nogal gelukkig dat van die woorde wat in Art. IV van die Nederlandsche Geloofsbelydenis volgens die deur PROF. Gooszen besorgde uitgawe van die Nederlandsche Bijbel-Compagnie, 1899, staan, nl. ,Jeremia en deszelfs Klaagliederen" die woorde ,en deszelfs Klaagliederen" in ander uitgawes van die Belydenis nie voorkom nie; anders was hier geleentheid vir 'n vyfde gravamen.

As ons die verrassende openheid van die nuwere Gereformeerde eksegete vir kritiese vraagstellinge opmerk, maar daarmee dogmatiese uitsprake van Gereformeerde skrywers vergelyk en daarby uit die literatuur in verband met die Dr. Geelkerken-saak en die Asser Sinode van die Gereformeerde Kerke van die jaar 1926 kennis maak met wat op die gebied van Bybelverklaring enersyds van Gereformeerde sy geskryf, andersyds as gesaghebbende dogmaties-kerklike standpunt ge-

4) Sien F. W. Grosheide, De Brief aan de Hebreën en de Brief aan Jakobus. Amsterdam 1927, bl. 36; dieselfde in die serie Korte Verklaring, 1935, 2de druk; ook PROF. J. A. C. vaN LEEUWEN in die Christelijke Encyclopaedie, Kampen, 2de dl., bl. 490; die Korte Christelijke Encyclopaedie, Kampen 1934, onder redaksie van Prof. Grosheide sê bl. 431 "De schrijver is Paulus niet." 
dikteer is, dan verbaas dit ons nie so groteliks meer nie dat 'n Gereformeerde predikant in vet letters laat druk: ,dat er in onze Gereformeerde Kerken de grootste verwarring heerscht inzake Schriftbeschouwing en Schriftgezag," ja dat hy beweer dat daar in hierdie kringe met Skrifbeskouing en Skrifgesag "gesold wordt" en dat daar in werklikheid in hierdie sake leervryheid heers..$^{49}$ )

Die nuwere Gereformeerde exegese is vir ons ' $n$ verrassende bewys vir die waarheid van die organiese eenheid van objektiewe Bybelondersoek, waarvan die ernstige, wetenskaplike ondersoeker van die Bybelteks nie kan loskom nie, al bring dit hom in nog soveel probleme en in stryd met geliefkoosde oorgelewerde beskouinge. Ook by die Gereformeerde wetenskaplike werker sal by sy stille arbeid aan die Bybelteks die nugtere woorde van PROF. KORFF instemming vind: „Wij zullen ons nooit meer door aprioristische redeneeringen laten brengen tot een theorie over den $\mathrm{Bijbel}$, volgens welke deze anders zou zijn, dan hij zichzelf aan ons biedt en wij met onze eigen oogen duidelijk zien."

.Het is toch eigenlijk wel heel verdrietig" skryf KorfF .,dat wij. die samen in Christus gelooven, in plaats van ons met elkander te verdiepen in den rijkdom van dat geloof en gemeenschappelijk te trachten dien rijkdom aan anderen nabij te brengen, altijd weer onderling moeten haspelen over theologische kwesties." Intussen skyn die uitwerking van geloof tot teologie onvermydelik te lei tot onderlinge verskille en onderlinge stryd. "Gelukkig maar" sê KorfF „wanneer die strijd op zoo waardige wijze gevoerd wordt als in het boek van BERKouwer geschiedt." s0) Ongelukkig as ons, soos professore Du TorT, vader en seun, in ' $n$ vyand-kompleks gevange is teenoor ieder wat dit met ons teologiese beskouings nie eens is nie, ${ }^{51}$ ) ongelukkig as ons ons laat verlei tot 'n uitsluitingsbeleid soos wat die redaksie van die voorgenome Afrikaanse Bybelverklaring gevoer het deur in onevangeliese en on-reformatoriese konfessiepraktyk, wat so groteliks deur vrees bepaal word. Ek eindig met die hoop uit te spreek dat ons studente, ons predikante, ons professore nooit in hierdie komplekse gevang sal word nie en dat ook hierdie nuwe akademiese jaar hulle werksaam sal vind in daardie organisme van waaragtige Bybelondersoek wat besiel en deurasem is van die Gees van Christus. Waar dif Gees van Christus is, daar is vryheid, daar sal ook die eenheid wat daar in Christus is, openbaar word.

B. Gemser

49) Sien die brosjure... $\mathrm{Zijn}$ de mannen van Assen zelf aanranders van het Schriftgezag?" Een conscientiekreet, door ..Een Gereformeerde Predikant," Bloemendaal, s.i. (2 jaar na "Assen" verskene), bl. 31, 48, 41 n. 49.

50) t.a.p., Algemeen Weekblad, 21 Juli 1939.

51) J. D. Du TorT, Die Bybel is die Woord van God. Die Verkennerreeks. no. 1. Stellenbosch, 1941, bl. 11, 12, 19, 46, S. Du Tort, 'n Nuwe Fase. bl. 13, r. 18 v. benede. 